\title{
МОБІЛЬНИЙ ЗАСТОСУНОК У СИСТЕМІ СОЦІАЛЬНО-ПСИХОЛОГІЧНОЇ РЕАБІЛІТАЦЇ̈ ТРАВМОВАНОЇ ОСОБИСТОСТІ
}

Презентовано погляд на мобільні застосунки як перспективний інструмент запобігання руйнівним наслідкам психотравматизації в період гібридної війни. Обстоюється думка, що реабілітаційні впливи мають у першу чергу допомогти постраждалим встановити причинно-наслідкові зв'язки між травматичними подіями і відповідною симптоматикою, тому ключовим завданням $\epsilon$ специфіковане інформування населення. Курс "Соціально-психологічна підтримка адаптації ветеранів”, інтегрований у застосунок “Карманный психолог”, представлено як інструмент такого інформування та опрацювання психотравматичного досвіду в парадигмі когнітивно-поведінкового підходу. Описано результати емпіричної перевірки ефективності згаданого застосунку. Наведено відомості щодо організації дослідження: тактики (план для двох нееквівалентних груп із попереднім і повторним вимірюванням та експериментальним впливом); вибірки (ветерани АТО - 57 чоловіків віком від 26 до 34 років, які повернулися із зони бойових дій від 3-х місяців до 1 року тому); порядку збирання та обробки даних (онлайн-анкетування за “Шкалою впливу подій”, визначення внутрішньогрупових норм, оцінка нормальності розподілу, визначення розбіжностей за t-критерієм Стьюдента). Визначено, що в результаті використання застосунку серед досліджуваних експериментальної групи найпомітніше послабилися тенденції уникання розмов і спогадів про травматичний досвід (шкала уникнення $\mathrm{t}=3,7$ при $\mathrm{p}=0,001)$, однак значущі зміни відбулися і за шкалами інтрузії $(\mathrm{t}=2,6$ при $\mathrm{p}=0,013)$ та гіперзбудження $(\mathrm{t}=2,2$ при $\mathrm{p}=0,034)$. 3'ясовано умови, за яких ефективність досліджуваного застосунку зберігатиметься: прихильні до технологій користувачі, їхня вмотивованість щодо самодопомоги та невисокі загальні показники психотравматизації. Запропоновано способи включення мобільного застосунку в психореабілітаційний процес на просвітницькому, діагностичному, базисному та профілактично-підтримувальному етапах.

Ключові слова: мобільні застосунки, психоедукація, соціально-психологічна реабілітація, психотравматизація.

M. S. Dvornyk

\section{MOBILE APPLICATION IN THE SYSTEM OF SOCIO-PSYCHOLOGICAL REHABILITATION OF TRAUMATIZED PERSONALITY}

It is presented a look at mobile applications as a perspective tool for preventing the devastating effects of psychotraumatisation during the hybrid war. It is argued that rehabilitation influences, first of all, should help the victim to establish causeeffect correlations between traumatic events and the corresponding symptoms, therefore the key task is the specific informing of the population. The course "Socio-psychological support for adaptation of veterans", integrated into the application "Pocket psychologist", is presented as a tool for such information and treatment of psychotraumatic experiences 
by means of a cognitive-behavioral approach. The results of empirical verification of this application effectiveness are described. Data on the research organization is provided: the tactics (plan for two non-equivalent groups with previous and repeated measurements and experimental influence); the sample (ATO veterans - 57 men from 26 to 34 years, 3 months to 1 year returned from the combat zone); the order of data collection and processing (online questionnaire by the "Impact of Event Scale", definition of intra-group norms, estimation of data distribution normality, definition of differences by t-Student criterion). It was determined that as a result of the application usage by the experimental group there was a tendency to decrease the avoidance of conversations and memories about the traumatic experience (the avoidance scale $t=3.7$, $\mathrm{p}=0.001)$, however, significant changes also occurred on the scale of intrusions $(t=2.6$, $\mathrm{p}=0.013)$ and hyperarousal $(\mathrm{t}=2.2, \mathrm{p}=0.034)$. There are outlined the conditions under which the effectiveness of the studied application will be persisted: the users who are adherent to technologies, their self-help motivation and the average levels of overall psychotraumatisation. The ways of inclusion of a mobile application into psychorehabilitation process on the educational, diagnostic, basic and preventive stages are offered.

Key words: mobile applications, psychoeducation, socio-psychological rehabilitation, psychotraumatisation.

Постановка проблеми. В умовах сучасної, так званої гібридної, війни в Україні психотравматизація особистості стає поширеним явищем не тільки серед комбатантів, а й серед їхнього оточення - родини, друзів, знайомих, які часто не знають, як поводитися при цьому і як реагувати на незнайомі стани. Не меншою мірою деструктивних наслідків воєнної психотравматизації зазнає і мирне населення, зокрема внутрішньо переміщені особи й ті, хто активно стежить за подіями дистанційно.

Отримання психологічної травми, як і фізичних ушкоджень, впливає на настрій, думки, поведінку постраждалого. Зміни в емоційності, втрата сну, нав'язливе повернення до травматичних подій подумки це цілком нормальні реакції на екстремальні події. Однак для декого вони можуть створювати тимчасові і лише незначні перешкоди в повсякденному житті, а декого - вкрай виснажувати і патологізувати. Типовим явищем, коли йдеться про подолання цих станів, стають такі самодеструктивні способи, як відсторонення від довірчих стосунків із близькими, паління, вживання алкоголю і наркотиків, незахищені й безладні статеві стосунки, занурення в депресію та психози, суїцидальні спроби. Тому нагальним завданням є розроблення заходів щодо запобігання такій поведінці.

На жаль, лише традиційні засоби психологічної практики не здатні повною мірою забезпечити протидію такій значній загрозі ментальному благополуччю українців, як війна. Саме тому пошук і застосування новітнього інструментарію, заснованого на актуальних і вже досить звичних способах поширення зцілювальних практик серед на- 
селення, набувають пріоритетного значення. Оскільки проникнення інформації та інформаційних технологій у повсякденне життя стає об'єктивним процесом і відбувається вже незалежно від бажання або волі людей, потрібно адаптуватися до нього, користуючись усіма його перевагами.

Поширення персональних електронних пристроїв та програмного забезпечення до них - мобільних застосунків - значно спрощує завдання інформування населення про вияви та наслідки психотравматизації. Саме навчальний компонент психореабілітації допомагає заохотити травмованих покладатися передусім на свої внутрішні сили, на власні мережі підтримки та власні судження, що зменшує необхідність у подальших заходах впливу і збільшує імовірність посттравматичного зростання.

Аналіз останніх досліджень і публікацій. На заході дослідження потенціалу мобільних застосунків для збереження ментального здоров’ я розпочалися з 2010-х років. Зокрема, ефективність таких електронних втручань аналізують у своїх роботах A. Aguilera et al. [1], A. M. Brown [2], J. Apolinario-Hagen et al. [3] та ін. Ідеї щодо розширення переліку надаваних психологічних послуг через смартфон-застосунки обстоюються в працях T. Donker et al. [4], B. E. Dicianno et al. [5], C. R. Whaley [6]. Деякі аспекти використання застосунків для післявоєнної реабілітації розглядають В. M. Kuehn [7] та N. E. Bush et al. [8]. Усі згадані автори одностайні щодо того, що мобільні застосунки мають як переваги, так i недоліки, які потрібно врівноважувати дотриманням певних вимог до якості самих застосунків і до стратегій їх імплементації в більш широкі контексти соціально-психологічних втручань.

У вітчизняній науковій літературі проблематика мобільних застосунків розглядається переважно під кутом зору інформаційних технологій і ще досить далека від психологічної практики. Зокрема, акцент робиться на електронних сервісах як інструментах комунікації та маркетингу. Огляд українськомовних психологічних застосунків (те саме, що й психологічні мобільні додатки) для опрацювання психотравматичних подій представлено в наших попередніх публікаціях.

Не вирішені раніше частини загальної проблеми. Маючи вагомий потенціал для інформування великої кількості населення про проблеми психотравматизації та способи ії подолання, українськомовні мобільні застосунки все ще не перевірені на ефективність і не можуть рекомендуватися для загального користування. Тому нагальним завданням $є$ наразі представлення емпіричних доказів щодо доцільності використання таких застосунків для зміни показників психотравматизації в кращий бік.

Метою статті $є$ опис експериментального дослідження ефективності курсу “Соціально-психологічна адаптація ветеранів” із застосунку 
“Карманный психолог”, а також обгрунтування місця курсу в психореабілітаційному процесі.

Виклад основного матеріалу дослідження. Травмована особистість - це суб'єкт, що пережив інтенсивний страх і безпомічність через значну загрозу своїй психологічній цілісності або загрозу благополуччю значущої особи. Якщо опрацювання травматичного досвіду особистості не відбувається вчасно або ж не відбувається взагалі, зростає ймовірність появи симптомів посттравматичного стресового розладу. Його базовими характеристиками є: 1) інтенсивне перепроживання травматичної події у формі інтрузивних спогадів (флешбеки, нічні кошмари) i формування неадекватних тригерів; 2) уникання думок, почуттів, ситуацій, які нагадують про травматичний досвід; 3) гіперзбудливість, що заважає нормальному сну та концентрації уваги, дратівливість й агресивність, надмірна настороженість і лякливість [9]. Однак у результаті когнітивного, емоційного та поведінкового опрацювання постраждалим свого травматичного досвіду стають можливими і посттравматичне зростання [10], успішна реінтеграція особистості в повсякденне життя [11]. Тому перше завдання психореабілітаційної роботи - це допомагати постраждалим усвідомити причинно-наслідкові зв'язки симптомів страждання 3 травматичною подією і запобігати виникненню тяжких постстресових станів. На цьому шляху найбільш ефективними показали себе засоби когнітивно-поведінкового підходу - i 3 погляду продуктивності, i 3 погляду швидкості опрацювання відповідної симптоматики.

Саме засоби когнітивно-поведінкового інформування покладено в основу інтегрованого у застосунок “Карманный психолог” українськомовного курсу "Соціально-психологічна підтримка адаптації ветеранів” (“СППА”), який було розроблено на основі однойменної тренінгової програми [4]. Його безкоштовно можна завантажити з платформи PlayMarket зі свого смартфона чи планшета й обрати в меню відповідний курс. Після введення контактних даних користувачеві на електронну пошту та безпосередньо в застосунок протягом 30 днів надходять щоденні листи з інформацією щодо постстресових станів та вправами на досягнення самоефективності.

Поєднання технік когнітивно-поведінкової терапії з електронним форматом інтервенцій у вищезазначеному застосунку зацікавило нас 3 погляду ефективності. Адже з-поміж інших українсько- і російськомовних психологічних застосунків саме курс "СППА" найбільшою мірою відповідав вимогам до електронних сервісів психореабілітації після травматичних подій [12].

Гіпотеза емпіричної перевірки ефективності зазначеного застосунку полягла в тому, що після 30 днів користування ним досліджувані демонструватимуть позитивні зміни у своєму психологічному стані. 
Як дослідницьку тактику було обрано план для нееквівалентних груп - із попереднім вимірюванням в експериментальній та контрольній групах, експериментальним впливом на першу групу і повторним заміром показників в обох групах.

У дослідженні взяли участь ветерани АТО з різних регіонів України - чоловіки віком від 26 до 34 років, які на момент збирання даних повернулися із зони бойових дій від 3 -х місяців до 1 року тому. До експериментальної групи увійшло 30 осіб, до контрольної - 27.

За незалежну змінну було взято критерій користування мобільним застосунком - номінативні дані контрольної та експериментальної груп. Залежну змінну було представлено рівнем психотравматизації, що вимірювався "Шкалою впливу подій" ("Impact of Event Scale" в адаптації Українського інституту когнітивно-поведінкової терапії). Ця методика складається з 22 тверджень-труднощів; досліджуваному пропонується визначити, наскільки ці труднощі виснажували його протягом останнього тижня, обравши один із запропонованих варіантів: "анітрохи" (0 балів), “трохи” (1 бал), “помірно” (2 бали), “досить сильно” (3 бали), "дуже сильно" (4 бали). Під час обробки аналізувалися сумарні бали та бали за трьома субшкалами: уникнення, інтрузії, гіперзбудження.

Для збирання експериментальних даних використовувалися онлайн-засоби. Інформацію про проведення дослідження було опубліковано на особистій сторінці автора з рандомними перепостами та запропоновано для поширення адміністраторам сторінок громадських організацій у соцмережі Facebook: “Товариство ветеранів ATO”, “Асоціація учасників бойових дій та учасників АТО”, "Побратими”, "Спілка учасників АТО України" “Серце воїна", "Союз учасників бойових дій”. Охочі взяти участь у дослідженні мали можливість звернутися до експериментатора і заповнити електронний бланк, що надсилався в особисті повідомлення, або онлайн-документ Google Forms за посиланням https://goo.gl/forms/udMqISUzp6MjnSgG2.

Упродовж періоду надходження даних за "Шкалою впливу подій” досліджувані почергово включалися до експериментальної та контрольної груп: першим надавалися інструкції щодо користування застосунком та повторного заповнення опитувальника по завершенні користування, другим - тільки заохочення до повторного заповнення опитувальника через 30 днів.

Контроль незалежної змінної відбувався на основі відсутності впливів будь-яких видів психологічної допомоги, окрім застосунку (для експериментальної групи), або лише фактору часу (для контрольної групи). Із досліджуваними попередньо обговорювалися їхні плани щодо отримання психологічної допомоги; якщо таких планів не було, респондент включався до вибірки. Під час повторного опитування до анкетних даних також було додано питання: “Чи користувалися ви 
якими-небудь видами психологічної допомоги, *окрім застосунку “Карманный психолог”? (*) - продовження для експериментальної групи). Бланки зі ствердними відповідями на це питання було виключено з аналізу (3 випадки).

Щоб визначити рівні психотравматизації досліджуваних, на основі отриманих за методикою даних було встановлено внутрішньогрупові норми. Для експериментальної групи: низький рівень - до 19 балів, нижчий від середнього - від 19 до 34 балів, середній - від 34 до 64 балів, вищий від середнього - від 64 до 79 балів, високий - понад 79 балів. Для контрольної групи, відповідно, низький рівень - до 13 балів, нижчий від середнього - від 13 до 30 балів, середній - від 30 до 63 балів, вищий від середнього - від 63 до 80 балів, високий - понад 80 балів.

Перші заміри психотравматизації показали переважання середніх показників як в експериментальній (23 особи), так і в контрольній (15 осіб) групі. Тобто більшість досліджуваних демонстрували помірні вияви симптомів уникнення, інтрузії та гіперзбудження (рис. 1).

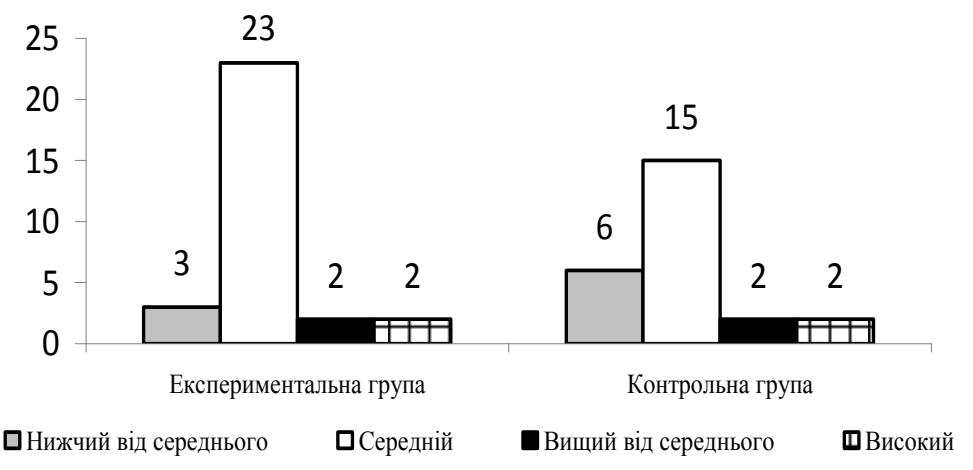

Рuc. 1. Рівні психотравматизації в учасників експериментальної та контрольної груп до експериментальних впливів

У результаті дії відповідних факторів - застосування мобільного додатку досліджуваними експериментальної групи і тільки плину часу для досліджуваних контрольної групи - було виявлено певні зміни в стані учасників. Так, в експериментальній групі значно збільшилася кількість осіб, які мають рівень психотравматизації нижчий від середнього (3 - до впливів і 13 - після впливів), з'явилась особа з низьким рівнем, а осіб з рівнем, вищим від середнього і високим, не виявлено взагалі. У контрольній групі другий замір, порівняно з першим, також засвідчив деякі зрушення: незначне збільшення кількості осіб із середнім рівнем психотравматизації (15 - до, 17 - після) і з високим рівнем стало на одну особу менше. 


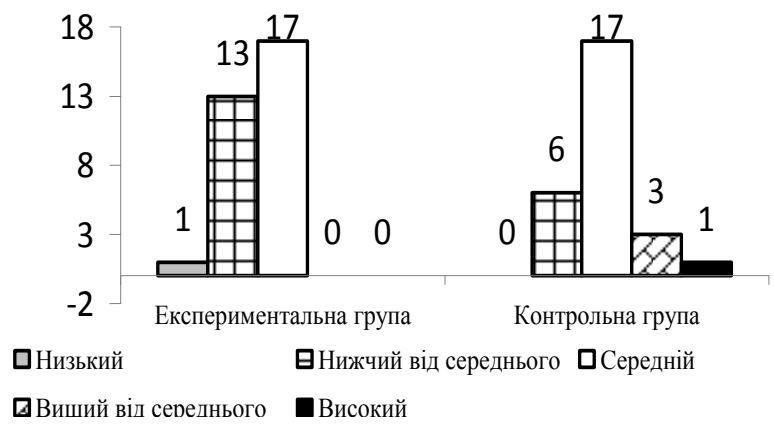

Puc. 2. Рівні психотравматизації в учасників експериментальної та контрольної груп після експериментальних впливів

Аби підтвердити достовірність розбіжностей у масиві отриманих результатів, було здійснено статистичні процедури в програмі SPSS 16.0. Першим кроком була перевірка вибірки на нормальність розподілу даних (тест "1-Sample K-S”). Оскільки показники рівня значущості (Asymp. Sig.) за кожною шкалою не перевищували 0,05 , розподіл даних було прийнято як близький до нормального. Тому для подальшої перевірки розбіжностей у групах до експериментального впливу і після нього можна було користуватися параметричним критерієм t-Стьюдента.

Завдяки опції "Independent Samples T-test" було виявлено значущі розбіжності між показниками експериментальної групи до і після того, як учасники користувалися мобільним застосунком. Так, за шкалою уникнення показник $\mathrm{t}$ становив 3,7 (при $\mathrm{p}=0,001$ ), за шкалою інтрузії $\mathrm{t}=2,6$ (при $\mathrm{p}=0,013$ ), за шкалою гіперзбудження $\mathrm{t}=2,2$ (при $\mathrm{p}=0,034)$. Як бачимо, рівні значущості не перевищували показник 0,05 за жодною шкалою, тому показники в групі до експериментальних впливів і після них можна вважати достовірно різними.

За такою ж процедурою було порівняно вимірювані дані в контрольній групі. Ці розбіжності не можна вважати достовірними, адже рівень значущості (Sig.) за кожною шкалою мав набагато більші значення, ніж 0,05: за шкалою гіперзбудження $\mathrm{p}=0,9$, за шкалою інтрузії $\mathrm{p}=0,86$, за шкалою уникнення $\mathrm{p}=0,85$. Отже, статистично значущих розбіжностей між показниками досліджуваних до і після часового проміжку в 30 днів у контрольній групі немає.

Спостерігаємо також певну симетричність між показниками критерію за шкалами. Так, найбільші розбіжності і в експериментальній, і в контрольній групах виявлено за шкалою уникнення. Тобто в результаті використання застосунку більшість досліджуваних перестали уникати розмов і спогадів про травматичний досвід, і така ж тенденція може бути ймовірною за звичайного плину часу. 
Загалом, у результаті проведених обчислень встановлено, що ефект від використання досліджуваними програми "Соціально-психологічна підтримка адаптації ветеранів" з мобільного застосунку "Карманный психолог" є статистично значущим, тому цей інструмент психологічної допомоги можна вважати ефективним.

Слід, однак, враховувати контингент досліджуваних, аби уникнути помилкової екстраполяції результатів на ширші вибірки, адже за інших умов користування застосунком могло б і не спрацювати. Поперше, учасниками дослідження були молоді особи, які вміють користуватися смартфоном, тому користування мобільним застосунком не викликало в них ускладнень і спротиву. По-друге, вони самі виявили бажання взяти участь у дослідженні, що вже їх певним чином характеризує: вони не мали ускладнень із вмотивованістю і від самого початку були відкритими до самодопомоги. По-третє, рівень їхньої психотравматизації був загалом середнім, тобто не йшлося про наявність важких станів. Отже, для комплексного опрацювання психотравматизації із симптомами уникнення, інтрузії та гіперзбудження досліджений мобільний застосунок $є$ дієвим лише з певними обмеженнями і врахуванням особливостей користувача.

3 огляду на такий результат можна констатувати, що навіть самостійне користування застосунком зменшує у постраждалих вияви симптомів психотравматизації, а в разі поєднання 3 очними інтервенціями може замінити чи суттєво розширити певні етапи реабілітації. Так, на просвітницькому етапі досліджуваний застосунок може стати якісним структурувальним інструментом, адже інформація подається користувачеві дозовано, не перевантажує сприйняття і зберігається на пристрої, тому до неї за потреби завжди можна повернутися. Курс “СППА” може значно спростити діагностичну частину реабілітаційного процесу, адже травмований, який уже орієнтується у власній симптоматиці завдяки попередньому інформуванню, надаватиме більш точні відомості про свої стани, менше вдаючись до катастрофізації чи применшення їхньої значущості. Якщо ж використовувати цей застосунок паралельно з базисним етапом очної психореабілітації, то доречним буде моніторинг емоційних, когнітивних та поведінкових змін, зокрема, завдяки функції “Щоденник настрою”. На підтримувально-профілактичній стадії інформаційний компонент "СППА” можна також окремо використовувати для запобігання ретравматизації.

Висновки. Психоедукація, покладена в основу сучасних смартфонзастосунків для збереження ментального здоров'я, $є$ потужним інструментом запобігання негативним наслідкам психотравматизації в широкому соціальному контексті. Досліджений курс "Соціально-психологічна підтримка адаптації ветеранів", інтегрований у застосунок “Карманный психолог”, продемонстрував свою ефективність у випадку самостійного використання його травмованими. Послаблення таких симптомів, як 
уникання, інтрузії та гіперзбудження, свідчить про те, що належне ставлення до поданої інформації та свідоме їі опрацювання, фасилітоване спеціально організованим віртуальним простором застосунку, можуть у перспективі взагалі позбавити необхідності додаткових реабілітаційних заходів. У випадку більш тяжких постстресових станів застосунок, зберігаючи такий цінний час очних зустрічей, може спростити та структурувати просвітницький і діагностичний етапи, збагатити базисний чи повністю замінити профілактично-підтримувальний. Відповідно, це формує запит на подальші розвідки щодо стратегій поєднання електронної самодопомоги та очних психореабілітаційних впливів.

\section{Список використаних джерел}

1. Aguilera, A., \& Muench, F. (2012). There's an app for that: Information technology applications for cognitive behavioral practitioners. The Behavior therapist/AABT, 35(4), 65.

2. Brown, A. M. (2016). An App for Every Psychological Problem: Vision for the Future (Doctoral dissertation, Regent University).

3. Apolinário-Hagen, J., Kemper, J., \& Stürmer, C. (2017). Public acceptability of E-mental health treatment services for psychological problems: A scoping review. JMIR mental health, 4(2):e10. doi: 10.2196/mental.6186.

4. Donker, T., Petrie, K., Proudfoot, J., Clarke, J., Birch, M. R., \& Christensen, H. (2013). Smartphones for smarter delivery of mental health programs: a systematic review. Journal of medical Internet research, 15(11):e247. doi: 10.2196/jmir.2791.

5. Dicianno, B. E., Parmanto, B., Fairman, A. D., Crytzer, T. M., Yu, D. X., Pramana, G., ... Petrazzi, A. A. (2015). Perspectives on the evolution of mobile (mHealth) technologies and application to rehabilitation. Physical therapy, 95(3), 397-405.

6. Whaley, C. R. (2018). Contemporary Telemental Healthcare Delivery: The Therapeutic Relationship and Applied Considerations. Western Undergraduate Psychology Journal, 6(1). Retrieved from https://ojs.lib.uwo.ca/index.php/ wupj/article/view/1973/1277.

7. Kuehn, B. M. (2011). Mobile PTSD care. Journal of the American Medical Association, 306(8), 815-815.

8. Bush, N. E., Dobscha, S. K., Crumpton, R., Denneson, L. M., Hoffman, J. E., Crain, A., ... Kinn, J. T. (2015). A virtual hope box smartphone app as an accessory to therapy: Proof of concept in a clinical sample of veterans. Suicide and Life Threatening Behavior, 45(1), 1-9.

9. Kuhn, E., Greene, C., Ruzek, J., Nguyen, T., Wald, L., Schmidt, J. ... Ruzek, J. (2014). Preliminary evaluation of PTSD Coach, a smartphone app for posttraumatic stress symptoms. Military medicine, 179, 12-18.

10. Титаренко, Т. М. (2017). Стратегії сприяння посттравматичному зростанню особистості. Психологічні науки: проблеми і здобутки, 10 (1), 217-232.

11. Lazorenko, B. P. (2017). Psychotrauma as a consequence of the hybrid war: alienation and assimilation of the traumatic experience. Психологічні науки: проблеми $і$ здобутки, 10 (1), 145-148.

12. Горбунова, В. В., Карачевський, А. Б., Климчук, В. О., Нетлюх, Г. С., \& Романчук, О. І. (2016). Соціально-психологічна підтримка адаптації ветеранів АТО: посібник для ведучих груп. Львів: Інститут психічного здоров’я Українського католицького університету. 


\section{References}

1. Aguilera, A., \& Muench, F. (2012). There's an app for that: Information technology applications for cognitive behavioral practitioners. The Behavior therapist/AABT, 35(4), 65.

2. Brown, A. M. (2016). An App for Every Psychological Problem: Vision for the Future (Doctoral dissertation, Regent University).

3. Apolinário-Hagen, J., Kemper, J., \& Stürmer, C. (2017). Public acceptability of E-mental health treatment services for psychological problems: A scoping review. JMIR mental health, 4(2):e10. doi: 10.2196/mental.6186.

4. Donker, T., Petrie, K., Proudfoot, J., Clarke, J., Birch, M. R., \& Christensen, H. (2013). Smartphones for smarter delivery of mental health programs: a systematic review. Journal of medical Internet research, 15(11):e247. doi: 10.2196/jmir.2791.

5. Dicianno, B. E., Parmanto, B., Fairman, A. D., Crytzer, T. M., Yu, D. X., Pramana, G., ... Petrazzi, A.A. (2015). Perspectives on the evolution of mobile (mHealth) technologies and application to rehabilitation. Physical therapy, 95(3), 397-405.

6. Whaley, C. R. (2018). Contemporary Telemental Healthcare Delivery: The Therapeutic Relationship and Applied Considerations. Western Undergraduate Psychology Journal, 6(1). Retrieved from https://ojs.lib.uwo.ca/index.php/ wupj/article/view/1973/1277.

7. Kuehn, B. M. (2011). Mobile PTSD care. Journal of the American Medical Association, 306(8), 815-815.

8. Bush, N. E., Dobscha, S. K., Crumpton, R., Denneson, L. M., Hoffman, J. E., Crain, A., ... Kinn, J. T. (2015). A virtual hope box smartphone app as an accessory to therapy: Proof of concept in a clinical sample of veterans. Suicide and Life Threatening Behavior, 45(1), 1-9.

9. Kuhn, E., Greene, C., Ruzek, J., Nguyen, T., Wald, L., Schmidt, J. ... Ruzek, J. (2014). Preliminary evaluation of PTSD Coach, a smartphone app for posttraumatic stress symptoms. Military medicine. 179, 12-18.

10. Tytarenko, T. M. (2017). Stratehii spryiannia posttravmatychnomu zrostanniu osobystosti [Strategies to promote post-traumaticpersonality development]. Psycholohichni nauky: problemy $i$ zdobutky [Psychological Sciences: Problems and Achievements], 10 (1), 217-232 (ukr).

11. Lazorenko, B. P. (2017). Psychotrauma as a consequence of the hybrid war: alienation and assimilation of the traumatic experience. Psycholohichni nauky: problemy $i$ zdobutky [Psychological Sciences: Problems and Achievements], 10 (1), 145-148.

12. Gorbunova, V. V., Karachevskyi, A. B., Klymchuk, V. O., Netliukh, H. S., \& Romanchuk, O. I. (2016). Sotsialno-psykholohichna pidtrymka adaptatsii veteraniv ATO: posibnyk dlia veduchykh hrup [Socio-psychological support for the adaptation of ATO veterans: a guide for leading groups]. Lviv: Institute of Psychic Health of Ukrainian Catholic University (ukr).

(C) Дворник М. С. 